\title{
Korleis sjukepleiarar brukar praksiserfaringar frå Madagaskar seinare i arbeidslivet
}

\section{Leif Steinar Alfsvåg}

Fagseksjonsleiar for bachelor i sjukepleie

Institutt for helse- og omsorgsvitskap, Høgskulen på Vestlandet, campus Stord

\section{Siri Nyen}

Intensivsjukepleiar, praksisfasilitator og studiekoordinator

Lovasoa, Madagaskar og Det Norske Misjonsselskap (NMS)

\section{Margrethe Bakstad Søvik}

Internasjonal koordinator

Fakultet for helsefag, VID vitenskapelige høgskole, studiested Bergen

Internasjonalisering

Læringsutbytte

Sykepleierutdanning

Interkulturell kompetanse

Kvalitativ studie

Sykepleien Forskning 2022;17(88305):e-88305

DOI: 10.4220/Sykepleienf.2022.88305

\section{Sammendrag}

Bakgrunn: Det er eit nasjonalt mål at halvparten av alle studentar skal ha eit utanlandsopphald i løpet av studietida. Studentutveksling har vist seg å vere viktig for å oppnå interkulturell kompetanse, men det manglar kunnskap om korleis sjukepleiarane nyttar denne kompetansen i framtidig arbeid. Slik kompetanse er sentral for å møte behovet om likeverdige helse- og sosialtenester i eit fleirkulturelt samfunn. 
Føremål: Føremålet med studien var å utvikle kunnskap om korleis norske ferdigutdanna sjukepleiarar brukar erfaringar frå praksisopphald i det globale sør, i arbeidslivet.

Metode: Studien har eit kvalitativt design der det er nytta både opne spørsmål i eit spørjeskjema ( $\mathrm{n}=77)$ og individuelle intervju $(\mathrm{n}=4)$ av ferdig utdanna sjukepleiarar som i studietida hadde praksis på Madagaskar. Dataa blei samla inn ved elektroniske spørjeskjema i mai 2020 og intervju hausten 2020 . Her fekk informantane spørsmål om praksisoppholdet på Madagaskar, og korleis dei brukar læringsutbytta frå praksis inn i arbeidslivet.

Resultat: Studien viser at erfaringar frå praksisopphald i det globale sør gir interkulturell kompetanse, men òg personleg og fagleg vekst. I etterkant peikar informantane på at dei som ferdigutdanna sjukepleiarar prøver å ha ei bevisst tilnærming til minoritetspasienten, ettersom dei hugsar korleis det kjendest å vere den som kom utanfrå. Perspektivet takksemd, som i stor grad er knytt til oppleving av ulikskapar i helsetenesta, har for mange gitt motivasjon til å arbeide for å realisere likeverdige helse- og omsorgstenester.

Konklusjon: Studien viser at sjukepleiarane har tileigna seg interkulturell kompetanse gjennom praksisperioden på Madagaskar. Dei rapporterer at dei brukar denne kompetansen aktivt i møte med pasientar frå andre kulturar. Funna våre indikerer at tidlegare utanlandsstudentar kan få ei brubyggjarrolle der dei ser behova til minoritetspasienten, samtidig som dei kan tilpasse dei til ein norsk kontekst. Dette kan tyde på at praksisutveksling til det globale sør også i framtida bør ha ein sentral plass i norsk sjukepleiarutdanning.

Talet på innbyggjarar med minoritetsbakgrunn er stadig aukande i Noreg (1). Dette inneber eit større kulturelt mangfald som fører med seg behov for utvida kompetanse hos sjukepleiarar $(2,3)$.

Eit tiltak for å dekkje behovet for likeverdige helse- og omsorgstenester kan vere større satsing på internasjonalisering i sjukepleiarutdanninga.

Kunnskapsdepartementet har sett som mål at halvparten av studentane har eit utanlandsopphald i løpet av studietida (4).

Internasjonalisering kan bidra til at dei enkelte studentane oppnår kunnskap om interkulturell forståing og får evner til å løyse problem, ta initiativ, ut øve kreativitet og drive samarbeid og omstilling (4). Dette er i tråd med forskrifta for norsk sjukepleiarutdanning: «Kandidaten skal bruke kunnskap om kulturkompetanse og kulturforståing i vurdering, planlegging, gjennomføring og evaluering av sykepleie» (5). 
I denne artikkelen byggjer me på Dahl si forståing av interkulturell kompetanse, altså «evnen til å kommunisere hensiktsmessig og passende i en gitt situasjon overfor andre mennesker med andre forutsetninger. Dette krever passende adferd, adekvat kunnskap og moralske holdninger» (6, s. 294).

Som eit ledd i internasjonalisering legg norske utdanningsinstitusjonartil rette for sjukepleiepraksis i det globale sør. Læringsutbyttet etter eit praksisopphald kan vere personleg og fagleg vekst, auka språkkompetanse, utvikling av interkulturell kompetanse og læring om global helse og helsesystem $i$ andre land (7-12).

Det er likevel ikkje sjølvsagt at relevant kompetanse følgjer med eit praksisopphald i det globale sør. Studiar viser at faktorar som språk og store forskjellar i ressursar og i utøving av sjukepleie mellom Noreg og praksislandet kan hindre kunnskapsutvekslinga i praksis (13). Resultatet er òg avhengig av god oppfølging og rettleiing av studentane (10-12).

Dei fleste tidlegare studiar av sjukepleiarutveksling til Afrika er gjorde like etter at studentane har vore på utveksling, og fortel ikkje så mykje om korleis sjukepleiarar tar med seg praksiserfaringar frå utlandet i seinare arbeid (10, 11, 13-15).

Tidlegare forsking ettersp $\varnothing$ r difor fleire studiar med informantar som er ferdig utdanna sjukepleiarar, og i kva grad ein kan bruke erfaringar frå praksisopphald under studietida i den noverande arbeidsrelasjonen ein har i helsevesenet $(8,16)$. Figur 1 viser fakta om Madagaskar. 


\section{Figur 1. Fakta om Madagaskar}

- Madagaskar er den fjerde største øya i verda.

- Landet har 28,5 millionar innbyggjarar.

- 75 prosent av befolkninga lever under fattigdomsgrensa på 1,9 USD per dag.

- 13 prosent har tilgang til elektrisitet.

- 20 prosent har tilgang til reint vatn $(17,18)$.

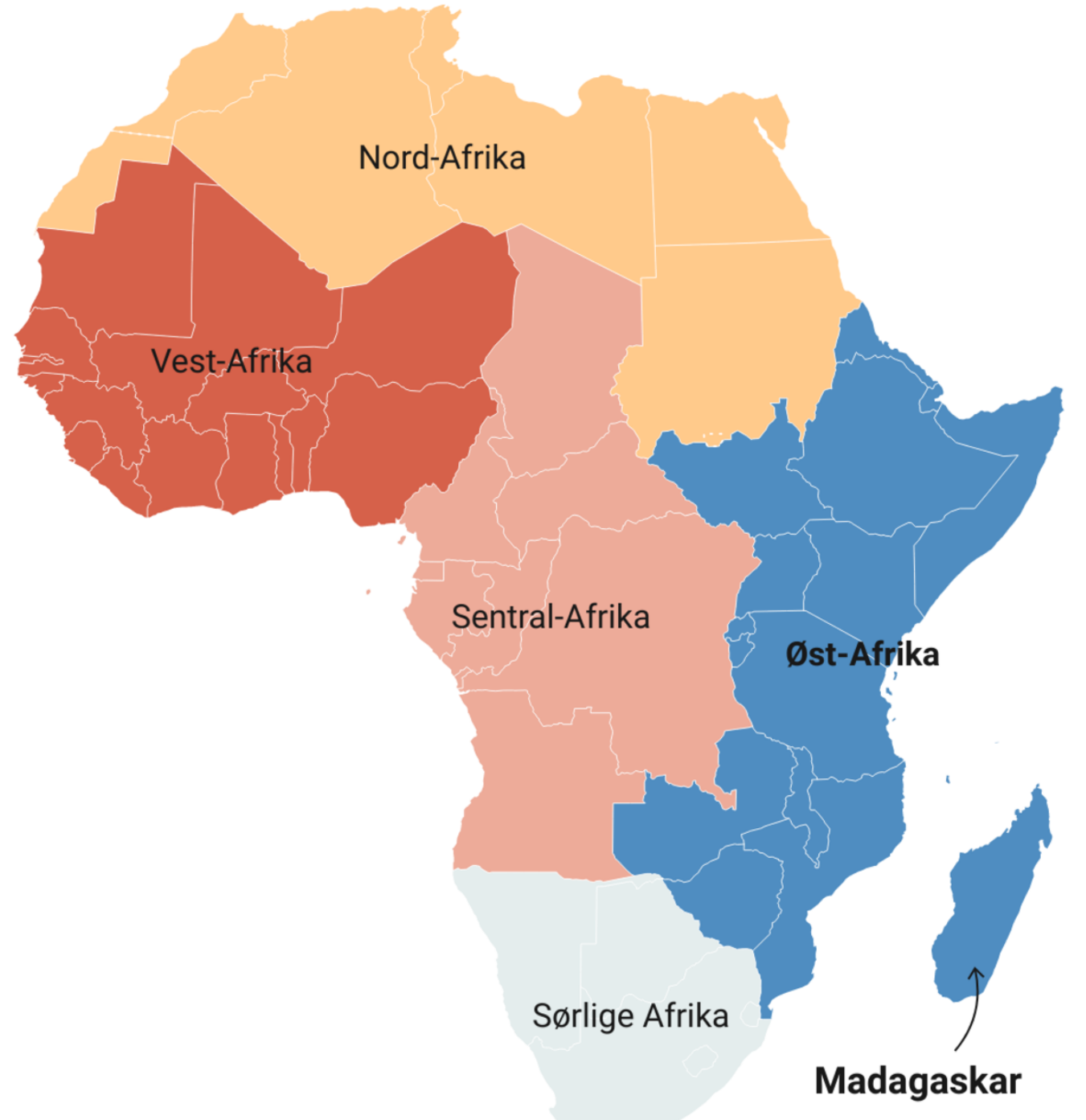

Laget med Datawrapper

\section{Føremål og forskingsspørsmål}

Føremålet med studien er å utvikle kunnskap om korleis ferdig utdanna sjukepleiarar brukar erfaringar frå praksisopphald i det globale sør i arbeidskvardagen i Noreg. Sentrale spørsmål er kva utbytte norske sjukepleiestudentar opplever å få ved å reise på utanlandsopphald til låginntekstland som Madagaskar, og korleis dei rapporterer å bruke dette utbyttet i arbeidslivet.

\section{Metode}


Studien har eit kvalitativt og utforskande design der det er nytta opne spørsmål i eit anonymt spørjeskjema og individuelle djupneintervju. Me har dermed fătt tilgang til eit større tilfang av svar gjennom spørjeunders $\varnothing$ kinga og samtidig gått meir i djupna når det gjeld den enkelte sine erfaringar, gjennom individuelle intervju (19).

\section{Materiale}

Data blei samla inn ved elektronisk spørjeskjema i mai 2020. I spørjeskjemaet blei informantane blant anna spurde om praksisoppholdet på Madagaskar og korleis dei brukar erfaringane frå dette i arbeidslivet. I dei individuelle djupneintervjua nytta me semistrukturert intervjumetode for å utforske kva informantane opplevde at dei hadde lært frå praksisperioden på Madagaskar, og korleis dei brukar denne kompetansen i sjukepleieyrket.

I intervjua brukte me ein intervjuguide som inneheldt 17 spørsmål som var fordelte på tre tematiske område. Intervjuguiden var utforma med mål om å få svar på forskingsspørsmålet. Informantane fekk fortelje fritt ut frå tematikkane, og nokre gongar dekte forteljingane deira fleire av spørsmåla i intervjuguiden.

Intervjua blei gjennomførte på Zoom hausten 2020 og blei spelte inn før dei blei ordrett transkriberte. Kvart intervju varte i mellom 45 og 60 minutt. Andreforfattaren har transkribert alle intervjua.

\section{Utval og datainnsamling}

I perioden frå hausten 2016 til og med våren 2019 hadde 120 sjukepleiestudentar frå fleire norske utdanningsinstitusjonar praksis ved ulike helseinstitusjonar på Madagaskar. Sjukepleiestudentane var knytte til eit lokalt kompetansesenter og var i praksis i mellom 4 og 12 veker. Informantane blei rekrutterte gjennom studiekoordinatoren ved senteret (SN) gjennom allereie eksisterande chattegrupper på Messenger.

Alle som hadde vore sjukepleiestudentar på Madagaskar i den aktuelle perioden, blei inviterte til å delta i denne studien. Kriteria for deltaking var fullført sjukepleiarutdanning, minst eitt års arbeidserfaring som sjukepleiar og praksisutveksling på Madagaskar under utdanninga.

Totalt 77 gjennomførte heile spørjeskjemaet og møtte kriteria til å vere informantar. Fire informantar blei rekrutterte via spørjeskjema og tok del i djupneintervjuet som blei gjennomført av førsteforfattaren (LSA) og ein kollega. Tabell 1 viser ei oversikt over informantane. 
Tabell 1. Oversikt over informantar - bakgrunnsdata

\begin{tabular}{|c|c|c|c|}
\hline \multicolumn{2}{|l|}{ Spørjeundersøking } & \multicolumn{2}{|l|}{ Prosent } \\
\hline Kjønn & Kvinne & 91 & 7 \\
\hline & Mann & 9 & 70 \\
\hline \multirow[t]{4}{*}{ Alder } & $20-25$ & 44 & 34 \\
\hline & $26-30$ & 48 & 37 \\
\hline & $31-40$ & 5 & 4 \\
\hline & $41-$ & 3 & 2 \\
\hline \multirow[t]{3}{*}{ Lengd på opphald } & 1 månad eller kortare & 45 & 35 \\
\hline & 1-2 månadar & 8 & 6 \\
\hline & 3 månadar eller lenger & 47 & 36 \\
\hline \multirow[t]{3}{*}{ Ferdig utdanna } & 1 år sidan & 42 & 32 \\
\hline & 2 år sidan & 27 & 21 \\
\hline & 3 år sidan & 31 & 24 \\
\hline \multirow[t]{4}{*}{ Noverande arbeidsstad } & Spesialisthelseteneste & 77 & 59 \\
\hline & Kommunal helseteneste & 18 & 14 \\
\hline & Privat helseteneste & 3 & 2 \\
\hline & Arbeider ikkje som sjukepleiar & 3 & 2 \\
\hline \multicolumn{4}{|l|}{ Djupneintervju $(n=4)$} \\
\hline Kjønn & Kvinner (4) & & \\
\hline
\end{tabular}

Laget med Datawrapper

\section{Dataanalyse}

Tekstane er analyserte ved hjelp av systematisk tekstkondensering etter Malterud (20), ein metode for innhaldsanalyse i fire trinn. Målet har vore å hente ut kunnskap om kva erfaringar informantane hadde med utanlandsopphaldet, og kva utbytte dette har gitt for seinare yrkesliv.

Analyseprosessen har gått fram og tilbake mellom dei ulike trinna i fleire fasar og har dermed ikkje hatt form som ein lineær prosess. I første trinn blei me kjende med materialet ved å lese tekstane kvar for oss. Dette gav oss ein indikasjon på førebelse tematikkar (20). 
Me las først svara på dei opne spørsmåla i spørjeundersøkinga og deretter intervjua. Tematikkane som viste seg i djupneintervjua, samsvarte med dei frå spørjeundersøkinga, og me fekk ei djupare forståing, men ikkje tilfang av nye tematikkar.

I andre trinn gjekk me tilbake til tekstane og identifiserte meiningsberande einingar. Me fargekoda einingane kvar for oss og såg at det utkrystalliserte seg ulike kodegrupper. Deretter kom me saman for å sikre at dei ulike meiningsberande einingane blei plasserte i rett kodegruppe.

I tredje trinn gjekk me over til å dele kodegruppene inn i fleire undergrupper. Dette utførte me først kvar for oss, og deretter kom me saman for å drøfte kva for undergrupper som var mest relevante for vidare arbeid med teksten.

Neste operasjon var å lage kondensat av innhaldet ved hjelp av kunstige sitat basert på ei oppsummering av fleire meiningsberande einingar frå same undergruppe. Undervegs i prosessen endra òg kodegruppene seg etter som undergruppene gav oss ny innsikt om kva som var relevant å ta med vidare i arbeidet.

Det fjerde og siste trinnet var å rekontekstualisere. Funna, som både er lojale mot det informantane fortalde, og som gir lesaren innsikt og forståing (20), samanfatta me i under- og hovudkategoriar, og til slutt presenterte me dei i resultatdelen.

Eit utdrag av analysearbeidet, frå trinn 2 til 4, er vist i tabell 2. Her avvik me litt frå Malterud (20), som i sin modell opererer med kategori og ikkje under- og hovudkategori. 
Tabell 2. Utdrag frå analysearbeid

\begin{tabular}{|c|c|c|c|c|c|}
\hline $\begin{array}{l}\text { Meiningsberande eining/ } \\
\text { illustrerande utsegn }\end{array}$ & $\begin{array}{l}\text { Kode- } \\
\text { gruppe }\end{array}$ & $\begin{array}{l}\text { Sub- } \\
\text { grupper }\end{array}$ & Kondensat & $\begin{array}{l}\text { Under- } \\
\text { kategoriar }\end{array}$ & $\begin{array}{l}\text { Hovud- } \\
\text { kategori }\end{array}$ \\
\hline $\begin{array}{l}\text { «Eg kan framleis kjenne på } \\
\text { ubehaget med det å vere kvit } \\
\text { og ikkje kunne språket. Då var eg i } \\
\text { ein minoritet, og eg tenkjer at det då } \\
\text { må vere endå meir utfordrande å } \\
\text { vere den som treng hjelp» (intervju } \\
\text { 2). }\end{array}$ & $\begin{array}{l}\text { Interkulturell } \\
\text { kommunikasjon }\end{array}$ & $\begin{array}{l}\text { Medkjensle og } \\
\text { empati }\end{array}$ & $\begin{array}{l}\text { Eg har kjent på } \\
\text { det å vere } \\
\text { utanfor, vere } \\
\text { annleis og ikkje } \\
\text { kunne språket. }\end{array}$ & $\begin{array}{l}\text { Opplevde } \\
\text { erfaringar av å } \\
\text { vere ein minoritet }\end{array}$ & $\begin{array}{l}\text { Interkulturell } \\
\text { kompetanse }\end{array}$ \\
\hline $\begin{array}{l}\text { «Eg har meir innsikt i kvifor } \\
\text { pårørande er så ekstremt viktige for } \\
\text { dei, og at dei ønskjer å ha dei med } \\
\text { seg under sjukehusopphaldet, fordi } \\
\text { det er dei vande til frå } \\
\text { heimlandet» (spørjeundersøking). }\end{array}$ & $\begin{array}{l}\text { Interkulturell } \\
\text { kompetanse }\end{array}$ & $\begin{array}{l}\text { Møte andre kulturar } \\
\text { Kulturkunnskap }\end{array}$ & $\begin{array}{l}\text { Eg har sett i } \\
\text { praksis kor viktig } \\
\text { familien er for } \\
\text { den sjuke. }\end{array}$ & $\begin{array}{l}\text { Opplevd } \\
\text { kunnskap om } \\
\text { annan kultur }\end{array}$ & $\begin{array}{l}\text { Interkulturell } \\
\text { kompetanse }\end{array}$ \\
\hline $\begin{array}{l}\text { «Eg set verkeleg pris på } \\
\text { helsevesenet me har i Noreg! Klarer } \\
\text { å sjå alle fordelar og kor heldige me } \\
\text { er som bur i landet me bur i, med } \\
\text { fritt sjukehusval og gratis } \\
\text { behandling om me skulle bli sjuke } \\
\text { og trenge hjelp» } \\
\text { (spørjeundersøking). }\end{array}$ & Indre ressursar & Takksemd & $\begin{array}{l}\text { Eg har no sett } \\
\text { kva naud og } \\
\text { fattigdom gjer i } \\
\text { praksis. Eg er så } \\
\text { takksam for } \\
\text { helsevesenet i } \\
\text { Noreg. }\end{array}$ & $\begin{array}{l}\text { Takksemd } \\
\text { gjennom nytt } \\
\text { perspektiv }\end{array}$ & $\begin{array}{l}\text { Personleg og } \\
\text { fagleg vekst }\end{array}$ \\
\hline $\begin{array}{l}\text { «Føler eg er meir rusta til å tole } \\
\text { uventa arbeidsoppgåver, og tenkjer } \\
\text { at eg kanskje har fătt litt hardare } \\
\text { hud» (spørjeundersøking). }\end{array}$ & Indre ressursar & $\begin{array}{l}\text { Våge å stå i og } \\
\text { møte utfordrande } \\
\text { situasjonar }\end{array}$ & $\begin{array}{l}\text { Eg har } \\
\text { blitt tøffare, } \\
\text { vågar å gå inn i } \\
\text { utfordrande } \\
\text { situasjonar og } \\
\text { «bli der». }\end{array}$ & $\begin{array}{l}\text { Oppleving av å } \\
\text { vere meir robust }\end{array}$ & $\begin{array}{l}\text { Personleg og } \\
\text { fagleg vekst }\end{array}$ \\
\hline $\begin{array}{l}\text { «Blei meir sjølvstendig, blei klar over } \\
\text { eigen kompetanse, fekk ein ro } \\
\text { over kven eg er som sjukepleiar» } \\
\text { (spørjeundersøking). }\end{array}$ & Indre ressursar & $\begin{array}{l}\text { Sjølvstendig og } \\
\text { trygg }\end{array}$ & $\begin{array}{l}\text { Eg er blitt meir } \\
\text { sjølvstendig og } \\
\text { trygg. }\end{array}$ & $\begin{array}{l}\text { Løysingsorientert } \\
\text { og sjølvstendig }\end{array}$ & $\begin{array}{l}\text { Personleg og } \\
\text { fagleg vekst }\end{array}$ \\
\hline $\begin{array}{l}\text { «Enkelte prosedyrar, som å leggje } \\
\text { inn venekanyle har blitt enklare } \\
\text { basert på erfaring frå praksis på } \\
\text { Madagaskar» (spørjeundersøking). }\end{array}$ & Basal-kunnskap & Prosedyrekunnskap & $\begin{array}{l}\text { Eg fekk utført } \\
\text { mykje } \\
\text { mengdetrening } \\
\text { på prosedyrar. }\end{array}$ & Fagleg utbytte & $\begin{array}{l}\text { Personleg og } \\
\text { fagleg vekst }\end{array}$ \\
\hline
\end{tabular}

\section{Etiske aspekt}

Studien er vurdert av Norsk senter for forskingsdata (NSD) med referanse 297455 . Informert samtykke er gitt av alle informantane.

\section{Resultat}

Funna frå studien viser at praksis på Madagaskar har ført til «interkulturell kompetanse» og «personleg og fagleg vekst», som har ein nytteverdi for sjukepleieutøvinga etter fullført utdanning (tabell 3). 


\section{Tabell 3. Skjematisk framstilling av resultat}

Erfaringar frå praksisopphald i det globale sør som norske ferdigutdanna sjukepleiarar rapporterer å bruke i arbeidslivet.

\begin{tabular}{l|l} 
Interkulturell kompetanse & Personleg og fagleg vekst \\
\hline $\begin{array}{l}\text { Opplevde erfaringar av å vere ein } \\
\text { minoritet }\end{array}$ & Takksemd gjennom nytt perspektiv \\
\hline Opplevd kunnskap om annan kultur & Oppleving av å vere meir robust \\
& Løysingsorientert og sjølvstendig \\
\hline & Fagleg utbytte \\
\hline
\end{tabular}

Laget med Datawrapper

\section{Interkulturell kompetanse}

\section{Opplevde erfaringar av å vere ein minoritet}

Når studentane beskriv opplevinga av å vere norsk student på Madagaskar og møtet med ein ny kultur, nyttar dei omgrep som å vere på utsida og åvere ein framand:

«Det er noko eg har tenkt mykje på i etterkant. Der fekk eg oppleve å vere den som er på utsida, den som blir sett på som annleis» (intervju 4).

Å vere på utsida blir av informantane skildra som eitubehag prega av einsemd og ei kjensle av å vere den som treng hjelp, men samtidig ikkje forstå kva som skjer. Informantane peikar på at dei som ferdigutdanna sjukepleiarar prøver å ha ei bevisst tilnærming til minoritetspasienten, ettersom dei hugsar korleis det kjendest å vere den som kom utanfrå:

«Eg er merksam på at når ein pasient ikkje kan språket godt, og så står me og snakkar vårt språk i vårt tempo. Det hugsar eg sjølv kunne vere ubehageleg, for eg fekk jo ingenting med meg. Eg prøver å unngå å snakke over hovudet på desse pasientane og i størst mogleg grad møte dei med å nytte tolk eller omsetjingsverktøy, slik at me kan få ei viss forståing av kvarandre» (intervju 1).

Fleire informantar peikar på at læringsutbyttet frå denne typen opplevingar har ein stor overføringsverdi i møte med pasientar frå andre kulturar i Noreg.

\section{Opplevd kunnskap om annan kultur}

Mange av informantane beskriv at dei opplever at det er lettare å møte pasientar frå ein annan kultur no enn før praksisoppholdet. Dei forklarer denne nye kunnskapen som innsikt i tradisjonar, verdisett og haldningar, som igjen gir større forståing hos informantane for den konteksten minoritetspasientar kan kome frå: 
«No forstår eg betre kulturen til pasientar frå andre land. Ein skjønar betre skepsisen til helsehjelp, positive og negative haldningar til helsepersonell. Det er lettare å forstå deira situasjon» (spørjeunders $\varnothing$ king).

\section{«Informantane opplever at det er lettare å møte pasientar frå ein annan kultur no enn før praksisoppholdet.»}

Kva plass dei pårørande har i helsestellet og omsorga, er eit tilbakevendande tema hos informantane. Ein informant har fătt større forståing for at pårørandehar behov for å vise medkjensle og ønskje ein familiemedlem god betring, medan mei Noreg er meir opptekne av reglar og rutinar:

«Me er veldig sånn: 'Nei, nei. Pasienten skal ha ro og berre ha maksimalt to bes $\varnothing \mathrm{k}$ på rommet, og heller ikkje ha så mykje besøk.' Men erfaringane ute har gjort at eg er ser litt annleis på dette no. At me må finne ei løysing som passar begge partar, slik at dei ikkje opplever seg avviste» (intervju 4).

Informantane fortel at dei har fått kunnskap om anna sjukdomsforståing. Ei beskriv korleis ho brukar praksiserfaringane frå ein landsby med mentalt sjuke pasientar, der trua på forheksing og utdriving av ånder var sentrale element:

«Eg ser veldig mange like trekk mellom dei pasientane me møtte i sjukelandsbyen på Madagaskar, og pasientane her med utanlandsk opphav. Dette med forheksing og vonde ånder og sånt. Eg blir etterspurd på arbeid for erfaringane mine om korleis ein skal møte pasientar som trur dei er forheksa» (intervju 1).

Samtidig er det fleire som uttrykkjer at dei strevar med å setje ord på korleis dei brukar erfaringane dei har fătt i praksis:

«Men sånn heilt konkret kva på Madagaskar som har gjort at eg gjer som eg gjer i pleia, det synest eg er vanskeleg å setje fingeren på» (intervju 3).

Informantane sit på ein kunnskap som dei ikkje heilt er klar over. Denne utsegna kan illustrere det tvitydige ved dette:

«Det er ikkje alltid eg har eit godt svar, men eg har jo noko innsikt eller nokre erfaringar å dele» (intervju 1).

\section{Personleg og fagleg vekst}


Takksemd gjennom nytt perspektiv

Informantane beskriv at opphaldet på Madagaskar gav dei ei stor oppleving av å kjenne på takksemd. Dei omskriv fenomenet takksemd kring ressursar i helsetenesta til personleg velstand og kor privilegerte meer i Noreg.

Sjukepleiarane hugsar møtet med pasientar som ikkje fekk livreddande behandling eller lindring for sterke smerter grunna ressursmangel ihelsetenesta. Mange av informantane uttrykkjer at det er nettopp desse møta som gir perspektiv:

«Eg er litt meir klar over eller har kjent på kroppen, desse store forskjellane i verda. At ein lever så innmari privilegert. Ein får jo eit heilt nytt perspektiv på ting» (intervju 3).

Nokre av informantane trekkjer òg inn at dette perspektivet bidrar til eit engasjement for endring heime i Noreg og ein bruk av vårt helsevesen somgagnaralle grupper. Ei seier det har blitt ei kampsak å bidra til likeverdige helsetenester for innvandrarkvinner ut frå dei erfaringane ho har frå Madagaskar. Informantane trekkjer fram dei som av ulike årsaker er marginaliserte:

«Eg jobbar innanfor rusfeltet, der det er mykje sår. Prøver no å overtale arbeidsgivaren til å la oss utføre enkle sårstell på pasientar som er dårlege til å følgje opp behandling. Dersom dei klarte å få dei forferdelege operasjonssåra me såg på Madagaskar, til å gro med berre gas og saltvatn, må me i eit velferdssamfunn som Noreg kunne tilby eit lågterskeltilbod for dei som ikkje klarer å følgje opp vanleg behandling» (spørjeundersøking).

\section{Oppleving av å vere meir robust}

Informantane skildrar opplevinga av å vere meir robust som å utvikle eigenskapar som mot, uthald, det å våge å stå i situasjonen og det å bli hardhuda. Både i spørjeundersøkinga og i intervjua fortel mange avinformantane om tøffe episodar dei har møtt i praksis. Døme kan vere barn som har døydd, foreldre somikkje har råd til å betale for behandling, eller situasjonar der pasientarblir behandla dårleg på grunn av lite ressursar eller kunnskap.

\section{«Informantane formidlar at utvekslingsopphaldet har utvikla dei både som menneske og som sjukepleiarar.»}

Informantane formidlar at utvekslingsopphaldet har utvikla dei både som menneske og som sjukepleiarar. Ei fortel at ho er i stand til å takle situasjonarheime på ein betre måte: 
«Erfaringane frå praksis på Madagaskar har også bidratt til at eg oftare våger å gå inn i situasjonar som eg sjølv synest er skremmande og utfordrande» (spørjeundersøking).

\section{Løysingsorientert og sjølvstendig}

Mange er opptekne av at tilhøva i eit lågkostland som

Madagaskar gjer at ein må tenkje og handle annleis, og at dette er eigenskapar eller kompetanse som er nyttig i det norske helsevesenet:

«Eg vil påstå at eg er mykje meir sjølvstendig og flink til å ta avgjerder, kan tenkje meir praktisk og utanfor boksen. Men òg det å vere fleksibel og løysingsorientert» (spørjeundersøking).

Eit av døma på det å bli meir løysingsorientert kjem fram hos ein av informantane som koplar erfaringane sine med gjenbruk og mangel på utstyr i praksis på Madagaskar til den konkrete arbeidssituasjonen i Noreg:

«Nokre episodar brenn seg fast, og no i dag, når det er pandemi i verda, brukar eg mine erfaringar frå å jobbe under kår der utstyr må brukast om igjen. Ein må tenkje annleis og kreativt når utstyr går tomt. Eg er blitt svært kreativ i tanken når det gjeld løysingsorientert sjukepleie» (spørjeundersøking).

\section{Faglegutbytte}

Fleire informantar opplevde at dei fekk eit direkte sjukepleiefagleg utbytte av praksisopphaldet på Madagaskar:

«Den kliniske erfaringa er nyttig å ha med seg. Eg lærte anatomi og fysiologi gjennom å ha praksis på ei kirurgisk avdeling og det å sjå konsekvensar av ubehandla tilstandar» (spørjeunders $\varnothing$ king).

Dette kom òg fram iutsegner om at eini utdanninga lærer mykje om det kliniske blikket, men i Noreg har ein ulike apparat som dekkjer over mykje av det ein lærer om klinisk blikk:

«Er me usikre, spring me og hentar eit apparat. På Madagaskar må ein tenkje sjølv og bruke det ein har» (intervju 4).

Andre peikar òg på verdien av mengdetrening i praksis på Madagaskar - til dømes vaksinasjon, innlegging av perifere venekanylar, unders $\varnothing$ king og behandling av barn. Slike utsegner tyder på at informantane oppfattar at det faglege læringsutbyttet frå praksisopphaldet er nyttig kompetanse i ein norsk arbeidskvardag. 


\section{Diskusjon}

Føremålet med studien er å utvikle kunnskap om korleis norske ferdigutdanna sjukepleiarar brukar erfaringar frå praksisopphald i det globale sør i arbeidslivet.

\section{Interkulturelle brubyggjarar}

Likeverdige helse- og omsorgstenester er eit mål for den norske velferdsstaten (2). Det betyr at tenester må tilpassast og leggjast til rette ut frå behovet til den enkelte (3). Barrierar som bidrar til å hindre likeverdige helsetenester til minoritetspasientar, har vist seg å vere språkbarrierar, låg helsekompetanse hos pasienten, liten tillit til helsevesenet, ulike syn på helse og sjukdom, og manglande kunnskap om kulturen til pasienten (3).

Alpers og Hanssen (21) fann i sin studie at norske sjukepleiarar manglar kunnskap om ikkje-vestleg sjukdomsforståing og medisinske tradisjonar. Dette bidrar til at det er vanskeleg for helsepersonell å forstå ønske, behov og åtferd i møte med minoritetspasientar og pårørande. Forsking viser òg at mangel på interkulturell kompetanse påverkar pasientbehandling og ulikskapar i helse (22).

Når informantane skildrar korleis dei brukar erfaringane frå praksis på Madagaskar, ser det ut til at dei har tileigna seg interkulturell kompetanse (6). Både i spørjeunders $\varnothing$ kinga og intervjua kjem det fram at informantane opplever at dei sjølve er blitt meir opne for at andre kan oppleve, erfare og tenkje annleis enn det dei sjølve gjer. I så måte ser me at dei har fătt innsikt i korleis ei anna tru, annan sjukdomskunnskap og ein annan måte å sjå pårørande si rolle på kan påverke det behovet pasienten har for sjukepleie.

\section{«Det å føle seg framand og utanforståande er erfaringar dei no brukar i møte med pasientar med innvandrarbakgrunn.»}

Fleire informantar beskriv korleis det å føle seg framand og utanforståande er erfaringar dei no brukar i møte med pasientar med innvandrarbakgrunn. Dette kan tyde på at praksisopplevingane gjer det enklare å forstå og vise empati i møte med pasientar med annan kulturell bakgrunn.

Informantane formidlar at dei tar i bruk ulike kommunikasjonsteknikkar, blant anna bruk av tolketeneste, for å auke forståing av kvarandre. Dette er funn som samsvarar med tidlegare studiar og viser at praksisopphald i det globale sør kan bidra til å bryte ned nokre av barrierane for likeverdige helsetenester til minoritetspasientar $(9,11)$. 
Funna våre indikerer at tidlegare utanlandsstudentar i beste fall får ei brubyggjarrolle der dei kan sjå behova til minoritetspasienten samtidig som dei kan tilpasse dei til ein norsk kontekst. Gjennom erfaringar frå Madagaskar har informantane forstått verdien av å ha kjennskap til bakgrunnen og kulturen til pasienten og kunne leggje til rette ut frå det. Dette er i tråd med det sentrale læringsutbyttet i forskrifta for norsk sjukepleiarutdanning (5), som nemnt i innleiinga.

I studien vår seier mange av informantane at dei har lært mykje av opphaldet på Madagaskar. Me ser samtidig at mange synest det er utfordrande å setje ord på alt dei har lært, og at dei strever med å omsetje erfaringane i praksis i arbeidslivet i Noreg, særleg innanfor det som gjeld interkulturell kompetanse.

Dette er ei velkjend utfordring ein finn i studiar om det å overføre læringserfaringar til berekraftig kunnskap for vidare praksis (23). Det kan tyde på at studentar i praksis i det globale sør i større grad enn andre studentar har behov for rettleiing og verktøy både undervegs og etter avslutta praksis, slik òg andre studiar viser til (10-12).

\section{Perspektivet takksemd og samfunnsengasjement}

I spørjeunders $\varnothing$ kinga gav mange informantar uttrykk for at eit av dei største utbytta dei hadde fått av praksis på Madagaskar, var å få perspektiv. I særleg grad var dette perspektivet knytt til møtet med fattigdom og mangel på ressursar i helsevesenet. Kan vedkjenninga informantane beskriv rundt kjensla av takksemd, ha relevans i arbeidslivet? I intervjua blir perspektivet takksemd knytt til eit stort engasjement for minoritetsgrupper og dei som fell litt utanfor systemet i Noreg.

Takksemd kan ha ein viktig funksjon ved å gi grunnlag for solidaritet med menneske som har det dårlegare enn oss. Stortingsmeldinga «En verden av muligheter» (4) peikar på samfunnsengasjement som utbytte for studentar som reiser ut, og at dette er ferdigheiter og eigenskapar som kan vere nyttige i seinare jobbsamanheng. Det blir i meldinga hevda at denne typen effekt kjem med sjølve utanlandsopphaldet meir enn med innhaldet i studiet eller praksisen. Det kan tyde på at perspektivet takksemd for fleire av informantane har blitt eit incitament til å arbeide for å realisere likeverdige helse- og omsorgstenester.

Opplevinga av takksemd er òg funne i andre studiar som observerer erfaringar ved å ha praksis i låginntektsland $(9,10)$. Men der Hovland og Johannessen (10) finn ei slags etnosentrisk takksemd der informantane viser ei nedlatande og kritisk haldning til helsevesenet og kompetansen til helsepersonellet i praksislandet, er informantane i vår studie generelt meir positive til det lokale helsevesenet. 
Me kan finne liknande haldningar blant nokre av våre informantar, men dei fleste av deltakarane i studien vår kommenterer likevel at dei er imponerte over kor mykje det lokale helsepersonellet fekk utretta med få ressursar.

Den ulike tilnærminga treng ikkje bety at informantane i vår studie er meir kultursensitive enn informantane i studien til Hovland og Johannessen (10), men kan vere eit resultat av at det har gått lenger tid frå dei var i praksis, til intervjua blei gjennomførte, enn i studien til Hovland og Johannessen. Samtidig vil den evna studentane har til å delta i eigenrefleksjon, oppfølging og rettleiing undervegs i praksisoppholdet, òg bidra til å påverke slike haldningar, slik Hovland og Johannessen òg peikar på.

\section{Personleg vekst}

I tråd med tidlegare rammeplan for sjukepleiarutdanninga (24) og ny forskrift (5) er det eit overordna mål at ein utdannar sjølvstendige, ansvarsbevisste og

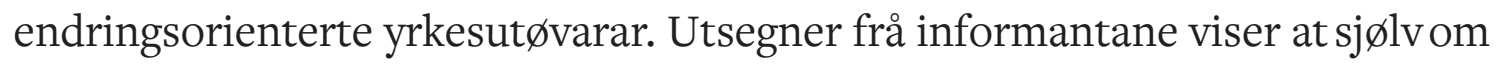
mange erfaringar frå praksis kunne vere «ubehagelege», har deilikevel greidd å trekkje relevant læring ut av opphaldet. Døme på slik læring er auka og utvikla innsikt i eigen kompetanse.

Både personleg og fagleg vekst er tema som kjem igjen i mange studiar som handlar om utbytte frå utveksling $(8,9,15,16)$. I vår studie diskuterer me korleis dette kjem til nytte i arbeidet som ferdig utdanna sjukepleiarar.

\section{«Deltakarane fortel at dei har fătt utvikla den kreative sida si, og at dei har opplevd å bli meir robuste og 'våge å stå i det'.»}

Ein studie (9) viser til at sjukepleiarstudentar som hadde hatt utanlandsopphald under studietida, hadde utvikla individuelle ferdigheitar og fått kulturell kompetanse som dei nytta seinare i arbeidslivet. Dette svarartil våre resultat, der deltakarane fortel at dei har fătt utvikla den kreative sida si, og at dei har opplevd å bli meir robuste og «våge å stå i det». Dette er viktige eigenskapar hos ein handlingskompetent sjukepleiar i ein krevjande arbeidskvardag i Noreg.

\section{Fagleg utbytte trass $i$ barrierar}

Ein studie samanliknar studentar som harvorei praksis i høvesvis høginntektsland og låginntekstland. I denne studien fann ein at det varvanskelegarefor studentar $i$ praksis i låginntektsland å oppnå eit fagleg læringsutbytte enn for studentari høginntektsland (7). 
I studien vår opplevde fleire informantarat deifekk kulturelt og personleg utbytte av praksisopphaldet, i tillegg til eit fagleg utbytte. Meir kunnskap innanfor anatomi og fysiologi, trening i å utøve det kliniske blikket og mengdetrening er område som informantane nemner spesifikt. Tidlegare studiar har i hovudsak sett på læringsutbytte i form av interkulturell kompetanse og personleg utvikling og lite på det faglege utbyttet av eit praksisopphald i det globale $s \varnothing \mathrm{r}(8,10,11)$.

Denne artikkelen viser at norske studentar også kan ha eit fagleg utbytte av slik praksis, trass i store sosioøkonomiske forskjellar og kulturbarrierar. Dette krev likevel at studentane er godt førebudde, at dei har klare arbeidskrav for praksisen, og at dei har rettleiarar som følgjer opp refleksjonane til studentane i praksisperioden $(8,9)$.

\section{Implikasjonar for utdanninga og vidare forsking}

Funna viser at informantane har læringsutbytte av praksis i det globale sør, men at det kan vere vanskeleg for deiå omsetje kompetansen i konkrete ord og handlingar. Det kan tyde på at studentari praksis i det globale sør i større grad har behov for rettleiing.

Denne rettleiinga bør leggje vekt på korleis studentane kan ta i bruk erfaringane og lære av dei, slik at dei kan få brukt kompetansen sin i ein norsk samanheng. Det er òg behov for meir forsking for å følgje opp det langsiktige utbyttet av internasjonal praksis og relevansen for arbeid i det norske helsevesenet.

\section{Sterke og svake sider}

Ein styrke ved studien er at me får kjennskap om praksiserfaringar både frå djupneintervju og fritekstsvar i spørjeunders $\varnothing$ kinga, sjølv om me berre har fire djupneintervju. Samtidig er nokre fritekstsvar korte. Me veit heller ikkje om dei vel 40 personane som ikkje svara på unders $\emptyset$ kinga, sit igjen med opplevinga av ikkje å ha lært noko.

Ei svak side ved studien er at han berre har informantar som har vore på Madagaskar, slik at me ikkje kan seie noko generelt om opplevingar frå praksis i andre land. Samtidig har me inkludert eit breitt utval tidlegare studentar frå ulike norske utdanningsinstitusjonar som har vore i praksis på Madagaskar i ein periode gjennom fleire år.

I vår studie har me ikkje unders $\varnothing \mathrm{kt} \mathrm{om} \mathrm{det} \mathrm{er} \mathrm{systematiske} \mathrm{forskjellar} \mathrm{mellom}$ erfaringar frå fire og tolv vekers praksis, men i gjennomgangen av materialet var det ikkje openberre forskjellar. Her vil det vere behov for ytterlegare studiar. 


\section{Konklusjon}

Studien viser at sjukepleiaranehar tileigna seg interkulturell kompetanse gjennom praksisperioden på Madagaskar som dei rapporterer å bruke aktivt i møte med pasientar frå andre kulturar. Mange av informantane beskriv at det er lettare å møte pasientar frå ein annan kultur no enn før praksisopphaldet, og at utvekslinga har gitt både fagleg og personleg utbytte.

Funna våre indikerer at tidlegare utanlandsstudentar kan få ei brubyggjarrolle der dei ser behova til minoritetspasienten samtidig som deikan tilpasse dei til ein norsk kontekst. Dette kan tyde på at praksisutveksling til det globale sør også i framtida bør ha ein sentral plass i norsk sjukepleiarutdanning.

\section{Kva studien gir av ny kunnskap}

- Tidlegare forsking viser at sjukepleiestudentar som har hatt praksis i det globale $s \varnothing r$, har opplevd personleg utvikling og tileigna seg interkulturell kompetanse, men me veit lite om korleis sjukepleiarane brukar dette i arbeidslivet.

- Me spurde ferdig utdanna sjukepleiarar som har jobba i helsesektoren i minst eitt år, og som var på utvekslingsopphold på Madagaskar i studietida, om kva dei hadde lært, og korleis dei brukte erfaringane og kunnskapen dei hadde tileigna seg, i arbeidslivet.

- Studien viser at sjukepleiarar som har hatt praksisopphald på Madagaskar, brukar erfaringane frå opphaldet i arbeidskvardagen, spesielt i møte med pasientar frå andre kulturar. Samtidig viser studien at sjølv om mange av sjukepleiarane seier dei lærte mykje av praksisopphaldet, så strevar dei med å beskrive konkret korleis dei brukar denne kunnskapen i praksis. Arbeidsgivarar bør leggje til rette for at desse sjukepleiarane får brukt erfaringane og kunnskapen sin. Studien rettar seg derfor ikkje berre mot UHsektoren, men òg praksisfeltet i Noreg.

\section{Referansar}

1. Folkehelseinstituttet. Befolkningen i Norge. Oslo: Folkehelseinstituttet; 2018. Tilgjengeleg frå: https://www.fhi.no/nettpub/hin/befolkning/befolkningen/ (lasta ned 07.04.2021).

2. Helse- og omsorgsdepartementet. Likeverdige helse- og omsorgstjenester god helse for alle. Regjeringen.no; 2013. Tilgjengeleg frå:

https://www.regjeringen.no/no/dokumenter/likeverdige-helse--og-

omsorgstjenester/id733870/ (lasta ned 07.04.2021). 
3. Jakobsen MD, Spilker RS. Innvandrere og brukermedvirkning i helse- og omsorgstjenestene. Hvordan ivareta innvandreres brukermedvirkning i avgjørelser om egen helse, utforming av tjenester og tjenesteforskning. En oppsummering av kunnskap. Senter for omsorgsforskning; 2020. Tilgjengeleg frå: https://omsorgsforskning.brage.unit.no/omsorgsforskningxmlui/handle/11250/2686528 (lasta ned 02.02.2022).

4. Meld. St. 7 (2020-2O21). En verden av muligheter - internasjonal studentmobilitet i høyere utdanning. Oslo: Kunnskapsdepartementet; 2020. Tilgjengeleg frå: https://www.regjeringen.no/no/dokumenter/meld.-st.-720202021/id2779627/ (lasta ned 07.04.2021).

5. Forskrift 25. januar $2008 \mathrm{nr} .128$ til rammeplan for sykepleierutdanning. Tilgjengeleg frå: https://lovdata.no/dokument/SF/forskrift/2008-01-25-128 (lasta ned 07.04.2021).

6. Dahl Ø. Møter mellom mennesker: innføring i interkulturell kommunikasjon. 2. utg. Oslo: Gyldendal Akademisk; 2013.

7. Granel N, Leyva-Moral JM, Morris J, Šáteková L, Grosemans J, BernabeuTamayo MD. Student's satisfaction and intercultural competence development from a short study abroad programs: A multiple cross-sectional study. Nurse Educ Pract. 2021;50(O1):102926. DOI: 10.1016/j.nepr.2020.102926.

8. Dietrich Leurer M, Kent-Wilkinson AE, Luimes J, Murray L, Squires V, Ferguson LM, et al. Reflections on study abroad: insights from registered nurses. Qual Adv Nurs Educ. 2020;6(1). DOI: 10.17483/2368-6669.1225

9. Jansen MB, Lund DW, Baume K, Lillyman S, Rooney K, Nielsen DS. International clinical placement - experiences of nursing students' cultural, personal and professional development: a qualitative study. Nurse Educ Pract. 2021;51(2):102987. DOI: 10.1016/j.nepr.2021.102987

10. Hovland OJ, Johannessen B. Sykepleierstudenter utvikler kulturell kompetanse på utveksling i Tanzania. Sykepl Forsk. 2018;(73782):e-73782. DOI: $\underline{10.4220 / \text { Sykepleienf.2018.73782 }}$

11. Ulvund I, Mordal E. The impact of short term clinical placement in a developing country on nursing students: a qualitative descriptive study. Nurse Educ Today. 2017;55(8):96-100. DOI: 10.1016/j.nedt.2017.05.013 
12. Gower S, Duggan R, Dantas JAR, Boldy D. Something has shifted: nursing students' global perspective following international clinical placements. J Adv Nurs. 2017;73(10):2395-406. DOI: 10.1111/jan.13320

13. Tjoflåt I, Razaonandrianina J, Karlsen B, Hansen BS. Complementary knowledge sharing: experiences of nursing students participating in an educational exchange program between Madagascar and Norway. Nurse Educ Today. 2017;49(O2):33-8. DOI: 10.1016/j.nedt.2016.11.011

14. Morgan DA. Learning in liminality. Student experiences of learning during a nursing study abroad journey: a hermeneutic phenomenological research study. Nurse Educ Today. 2019;79(8):204-9. DOI: 10.1016/j.nedt.2019.05.036

15. Edmonds ML. An integrative review of study abroad programs for nursing students. Nurs Educ Perspect. 2012;33(1):30-4. DOI: 10.5480/1536-5026-33.1.30

16. Roy A, Newman A, Ellenberger T, Pyman A. Outcomes of international student mobility programs: a systematic review and agenda for future research. Stud High Educ. 2019;44(9):1630-44. DOI: 10.1080/03075079.2018.1458222

17. Verdsbanken. The World Bank in Madagascar. Tilgjengeleg frå: https://www.worldbank.org/en/country/madagascar/overview\#1 (lasta ned 01.09.2021).

18. FN-sambandet. Madagaskar. Tilgjengeleg frå: https://www.fn.no/Land/madagaskar (lasta ned 01.09.2021).

19. Kvale S, Brinkmann S. Det kvalitative forskningsintervju. 3. utg. Oslo: Gyldendal Akademisk; 2015.

20. Malterud K. Kvalitative forskningsmetoder for medisin og helsefag. 4. utg. Oslo: Universitetsforlaget; 2017.

21. Alpers L-M, Hanssen I. Caring for ethnic minority patients: a mixed method study of nurses' self-assessment of cultural competency. Nurse Educ Today. juni 2014;34(6):999-1004. DOI: 10.1016/j.nedt.2013.12.004

22. Papadopoulos I, Shea S, Taylor G, Pezzella A, Foley L. Developing tools to promote culturally competent compassion, courage, and intercultural communication in healthcare. J Compassionate Health Care. 2016;3(1):2. DOI: $\underline{10.1186 / \mathrm{s} 40639-016-0019-6}$ 
23. Askeland GA, Døhlie E, Grosvold K. International field placement in social work: relevant for working in the home country. Int Soc Work. 2018;61(5):692-705. DOI: $10.1177 / 0020872816655200$

24. Kunnskapsdepartementet. Rammeplan for sykepleierutdanning. Oslo: Kunnskapsdepartementet; 2008. Tilgjengeleg frå:

https://www.regjeringen.no/globalassets/upload/kd/vedlegg/uh/rammeplaner/helse/ rammeplane_sykepleierutdannin_o8.pdf (lasta ned 07.04.2021). 